\title{
PENGEMBANGAN E-MODUL STRUKTUR ATOM UNTUK MENDUKUNG PERKULIAHAN KIMIA DASAR BERBASIS BLENDED LEARNING
}

\section{DEVELOPMENT OF E-MODULE ATOMIC STRUCTURE TO SUPPORT BASIC CHEMISTRY COURSES ON BASED BLENDED LEARNING}

\author{
Andri Wahyu Wijayadi ${ }^{1 *}$, Elcha bagus Narendra Putra ${ }^{2}$ \\ ${ }^{1}$ Fakultas Ilmu Pendidikan Universitas Hasyim Asy'ari \\ Jl. Irian Jaya No. 55 Tromol Pos XI Tebuireng Jombang \\ ${ }^{2}$ SMK PGRI Lawang \\ Jl. Dr. Wahidin No. 17 Lawang Malang \\ *e-mail korespondensi: diaandri@gmail.com
}

\begin{abstract}
Abstrak
Penelitian ini bertujuan untuk mengembangkan e-modul struktur atom berbasis electronic publication $(e P U B)$ dan mengetahui validitas dan kelayakannya untuk mendukung perkuliahan kimia dasar berbasis blended learning. Penelitian pengembangan ini menggunakan model Borg dan Gall. Penelitian terdiri lima langkah yaitu melakukan analisis produk yang akan dikembangkan, mengembangkan produk awal, validasi ahli dan revisi, uji coba lapangan, dan analisis hasil uji coba dan revisi produk. Subjek penelitian terdiri dari 3 ahli dan 30 mahasiswa prodi Pendidikan IPA Universitas Hasyim Asy'ari. Teknik pengumpulan data penelitian menggunakan angket skala Likert 1 - 4. Hasil penelitian dianalisis secara kuantitatif menujukkan e-modul yang telah dikembangkan memenuhi persyaratan validitas dan kelayakan untuk mendukung perkuliahan kimia dasar berbasis blended learning.
\end{abstract}

Kata kunci: blended learning, e-modul, struktur atom

\begin{abstract}
This research aims to develop atomic structure e-module based on electronic publication (ePUB) and find out their validity and applicability to support basic chemistry courses based on blended learning. This development research uses the Borg and Gall models. The research consists of five steps, analyzing the product to be developed, developing initial products, validating experts and revisions, field trials, and analyzing the result of trials and product revisions. The research subject consisted of three experts and 30 students of science education study program at Hasyim Asy'ari University. Research data collection techniques using Likert scale questionare $1-4$. The result of the research were analyzed quantitatively showing the e-module that have been developed to meet the validity and appropriateness to support basic chemistry courses based on blended learning.
\end{abstract}

Keywords: blended learning, e-module, atomic structure

\section{PENDAHULUAN}

Kimia adalah ilmu yang mempelajari tentang materi dan perubahan yang menyertainya (Chang, 2010: 4). Chomchid, 2008: 6; Ozmen, 2004: 152 menyatakan bahwa untuk memahami konsep-konsep penting dalam kimia diperlukan pengetahuan dasar mengenai konsep struktur atom. Dengan demikian struktur atom merupakan konsep yang penting di dalam kimia. Beberapa hasil penelitian menunjukkan jika banyak siswa yang mengalami kesulitan dalam mempelajarinya (Erduran \& Scerri, 2002: 19; Taber, 2001: 125). Kesulitan tersebut berdampak pada rendahnya pemahaman terhadap struktur atom dan menyebabkan terjadinya miskonsepsi (Nakiboglu, 2003). 
Hasil penelitian yang dilakukan oleh Wardhani, dkk (2016) terhadap mahasiswa calon guru kimia pada tahun ketiga yang telah menempuh matakuliah kimia dasar pada semester 1 dan 2 didapatkan fakta bahwa pemahaman terhadap struktur atom tergolong pada kategori cukup dan masih ditemukan miskonsepsi. Salah satu faktor penyebab terjadinya miskonsepsi yang terjadi pada topik struktur atom adalah karakteristik materi (Nakiboglu, 2003). Karakteristik materi pada topik struktur atom terdiri atas konsep-konsep yang bersifat abstrak. Oleh karena itu diperlukan cara yang tepat untuk mengajarkan materi yang bersifat abstrak tersebut sehingga tidak berdampak pada terjadinya miskonsepsi.

Salah satu cara yang dapat mengantisipasi hal tersebut adalah dengan mengajarkan konsepkonsep yang abstrak tersebut dengan cara memvisualisasikan dalam bentuk gambar, video, atau animasi. Visualisasi konseptual sangat penting dalam sains (Gilbert, 2005). Beberapa hasil penelitian yang mendukung tentang penggunaan visualisasi konseptual dalam pembelajaran kimia (Stief, 2005; Sanger dkk, 2007; Falvo, 2008). Visualisasi yang tepat tentang suatu konsep dapat digunakan sebagai analogi yang berfungsi mengkonkritkan pengetahuan yang bersifat abstrak.

Kemajuan teknologi informasi dan komunikasi (Information and Communication Technology, ICT) telah banyak diintegrasikan ke dalam proses pembelajaran. Salah satunya adalah pembelajaran online (web based). Melalui pembelajaran tersebut diharapkan terjadi peningkatan efektifitas dan efisiensi pembelajaran dibandingkan pembelajaran tatap muka. Namun hasilnya kurang konsisten dalam meningkatkan hasil belajar (Passerini, 2007). Mengacu pada hal tersebut memunculkan ide untuk menggabungkan pembelajaran online dengan pembelajaran tatap muka. Srategi pembelajaran tersebut dikenal sebagai pembelajaran blended learning.

Salah satu komponen penting untuk menunjang keberhasilan pembelajaran adalah ketersediaan bahan ajar. Hal yang sama berlaku juga untuk pembelajaran blended learning. Oleh karena pembelajaran pada blended learning berlangsung secara online dan offline, maka diperlukan bahan ajar yang dapat mendukung kedua kegiatan tersebut. Salah satu bahan ajar yang dapat digunakan untuk mendukung pembelajaran tersebut adalah e-modul berbasis ePUB (electronic publication). e-Modul berbasis
ePUB dapat memuat media dalam bentuk gambar, audio, video, dan animasi. Penggunaannya juga mudah sebab dapat dibaca pada berbagai perangkat seperti komputer/laptop dan handhphone. Dengan demikian e-modul berbasis $e P u B$ dapat diakses dimanapun dan kapanpun.

Berdasarkan uraian tersebut maka dilakukan penelitian untuk mengembangkan emodul struktur atom yang dapat mendukung pembelajaran kimia dasar berbasis blended learning. Tujuan dari penelitian ini untuk mengembangkan e-modul struktur atom berbasis $e P U B$ dan mengetahui validitas dan kelayakan e-modul yang dihasilkan.

\section{METODE PENELITIAN}

Penelitian ini termasuk penelitian pengembangan. Model pengembangan mengadaptasi prosedur penelitian pengembangan Borg dan Gall (Puslitjaknov, 2008) yang terdiri dari 5 langkah yaitu: 1) Melakukan analisis produk yang akan dikembangkan, 2) Mengembangkan produk awal, 3) Validasi ahli dan revisi, 4) Uji coba lapangan, dan 5) Analisis hasil uji coba dan revisi produk. Subjek penelitian adalah ahli materi, ahli media, ahli bahasa, dan 30 mahasiswa prodi pendidikan IPA Universitas Hasyim Asy'ari. Teknik pengumpulan data penelitian menggunakan angket skala Likert 1 4. Instrumen penelitian berupa angket validasi ahli dan angket respons mahasiswa. Hasil penelitian dianalisis secara kuantitatif menggunakan rumus:

\section{Persentase $=\frac{\sum \text { skor penilaian angket }}{\sum \text { skor maksimum }}$ X 100\%}

Untuk menentukan kualitas produk menggunakan kriteria pada Tabel 1.

Tabel 1. Kriteria Validitas Produk

\begin{tabular}{cc}
\hline Persentase & Kriteria \\
\hline $75,01 \%-100,00 \%$ & Sangat valid \\
\hline $50,01 \%-75,00 \%$ & Cukup valid \\
\hline $25,01 \%-50,00 \%$ & Tidak valid \\
\hline $00,00 \%-25,00 \%$ & Sangat tidak valid \\
\hline
\end{tabular}

\section{HASIL DAN PEMBAHASAN}

Pada tahap analisis produk yang akan dikembangkan diperoleh informasi awal: mahasiswa cenderung kurang aktif selama pembelajaran karena tidak memiliki sumber belajar, mahasiswa hanya menggunakan sumber 
belajar yang diberikan oleh dosen berupa handout pada saat pembelajaran berlangsung, karakteristik materi struktur atom yang abtstrak membuat dosen lebih banyak menjelaskan materi perkuliahan melalui metode ceramah, hanya sebagian mahasiswa yang memiliki laptop/komputer namun semuanya memiliki handphone. Berdasarkan informasi awal yang diperoleh maka diperlukan pengembangan bahan ajar yang dapat meningkatkan aktivitas belajar mahasiswa selama pembelajaran dan dapat diakses dengan mudah kapanpun dan dimanapun menggunakan peralatan yang dimiliki oleh semua mahasiswa yaitu handphone.

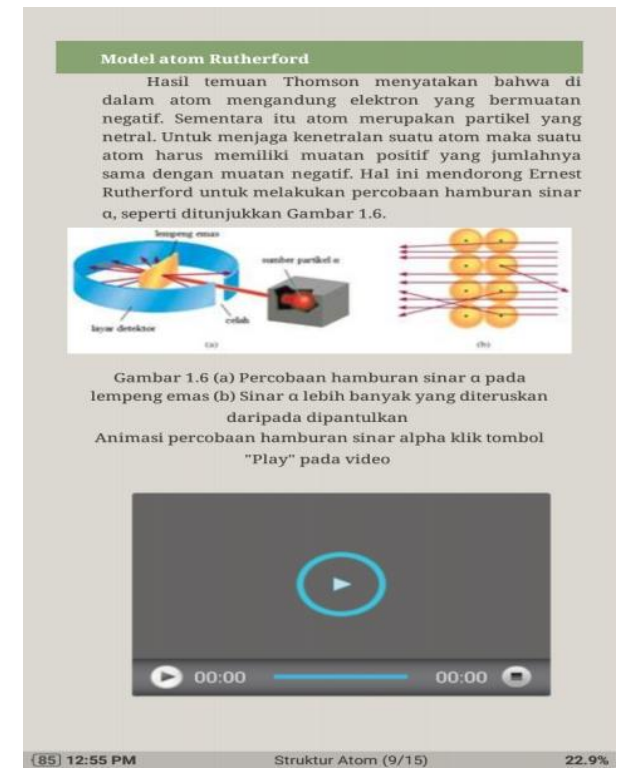

Berdasarkan hasil analisis produk dikembangkan produk berupa e-modul struktur atom yang berbasis $e P U B$. e-Modul berisi tiga kegiatan belajar, dimana pada setiap kegiatan belajar terdiri atas Tujuan, Uraian Materi, Rangkuman, Tugas Individu, Tugas Kelompok, dan Evaluasi. Tujuan menjelaskan kompetensi yang harus dikuasai oleh pengguna setelah mempelajari setiap kegiatan belajar. Uraian materi berisikan penjelasan setiap kompetensi yang harus dikuasai. Pada uraian materi disediakan visualisasi berupa gambar dan animasi/video untuk memperjelas materi. Contoh visualisasi dalam e-modul dapat dilihat pada Gambar 1.

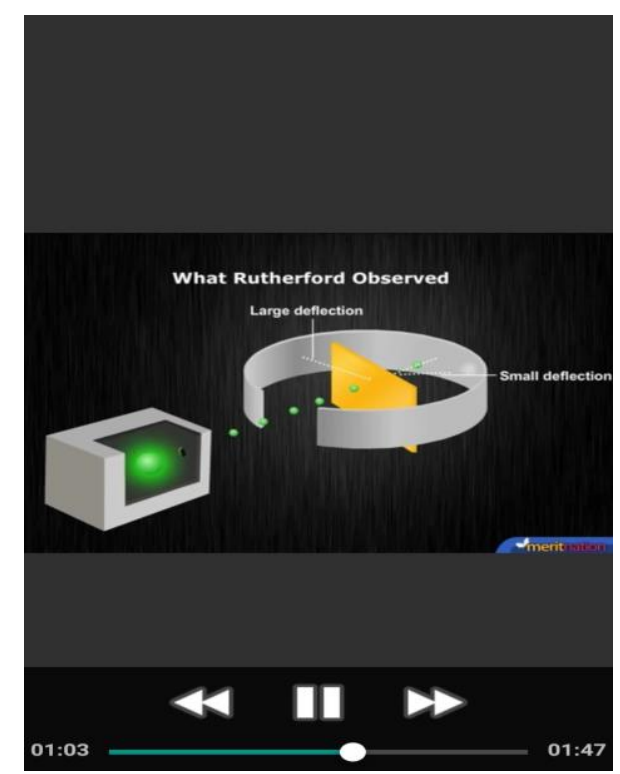

Gambar 1. Visualiasi gambar dan animasi pada e-modul

Visualisasi unggul dalam membantu mahasiswa membangun model mental terhadap kajian submikroskopis dan simbolik kimia. Keunggulan visualisasi dalam pembelajaran tersebut sebagai picture superior effect (Anglin, dkk dalam Kirna, 2014).

Tugas individu berisi pertanyaanpertanyaan yang berfungsi untuk mempersiapkan mahasiswa sebelum pembelajaran berlangsung. Egen \& Kauchak (2004) menyatakan bahwa pengetahuan yang baru bergantung pada pengetahuan awal yang dimiliki oleh pembelajar. Dengan mengerjakan tugas individu sebelum pembelajaran membuat mahasiswa mempunyai modal awal ketika pembelajaran. Modal awal yang dimiliki diharapkan membuat mahasiswa menjadi lebih aktif selama pembelajaran berlangsung.

Tugas kelompok berisi pertanyaanpertanyaan yang harus diselesaikan melalui kerja kelompok pada saat pembelajaran berlangsung. Schunk, dkk (2008) menyatakan bahwa pembelajaran menjadi lebih termotivasi dengan memberikan tugas yang mendorong mereka aktif. Tugas yang diberikan akan mendorong terjadinya interaksi antara mahasiswa dengan konten, mahasiswa dengan mahasiswa, dan mahasiswa dengan dosen. Interaksi sosial merupakan bagian penting dalam belajar konstrutivis (Vygotsky dalam Eggen \& Kauchak, 2004).

Evaluasi berisi soal-soal yang akan mengukur tingkat pemahaman pada setiap kegiatan belajar. Dengan adanya evaluasi tersebut maka setiap mahasiswa dapat mengetahui tingkat pemahamannya. Evaluasi yang dilakukan disini termasuk ke dalam refleksi pembelajaran. Schunk, dkk (2008) menyatakan bahwa pembelajaran konstruktivis 
mendorong siswa melakukan refleksi terhadap cara berpikirnya.

Tugas individu, tugas kelompok, dan evaluasi yang dikembangkan pada e-modul bersifat online dengan berbantuan aplikasi google form. Oleh karena itu dalam penyelesaiannya membutuhkan aktivitas online dari pengguna e-modul. Adanya aktivitas online dalam e-modul untuk mendukung pembelajaran yang berbasis blended learning. Beberapa tampilan konten offline dalam e-modul disajikan pada Gambar 2, sedangkan tampilan konten online dalam e-modul disajikan pada Gambar 3 .
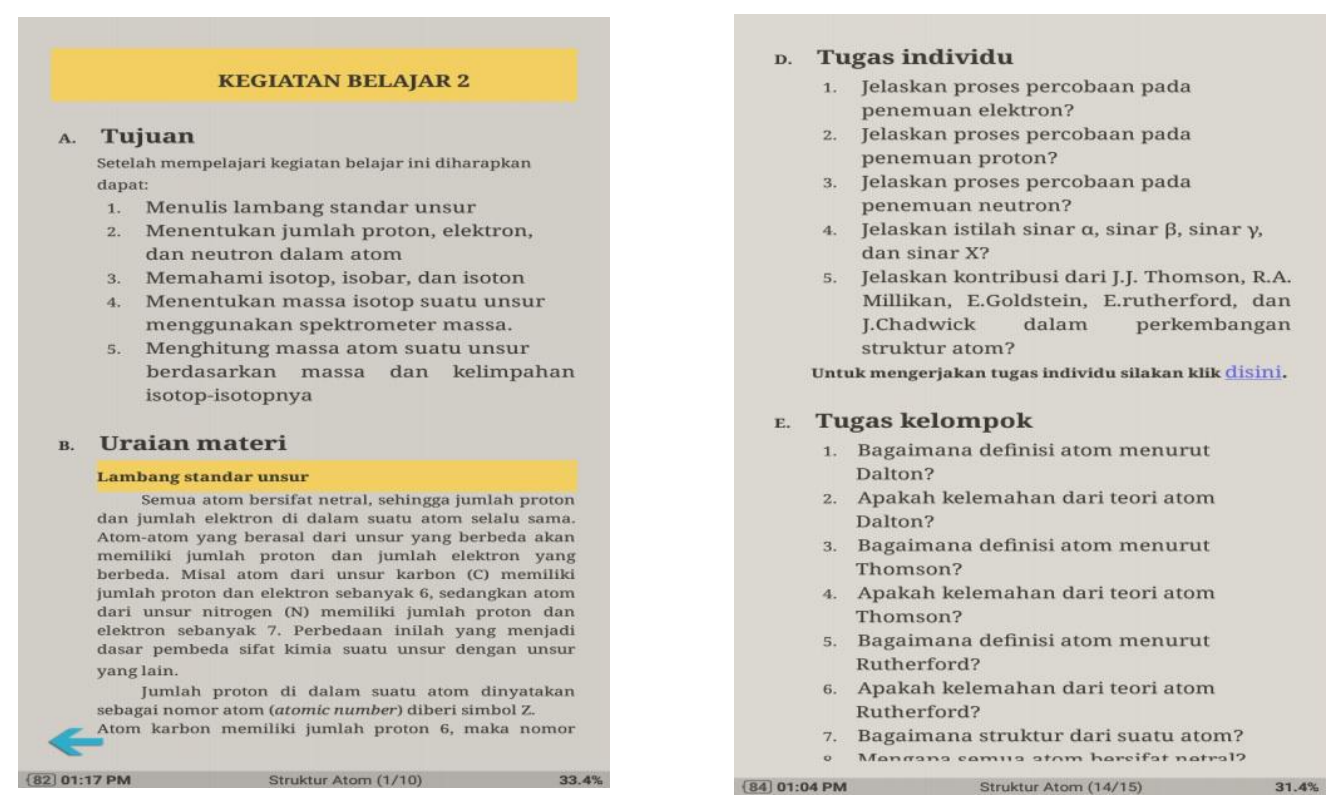

Gambar 2. Konten offline pada e-modul
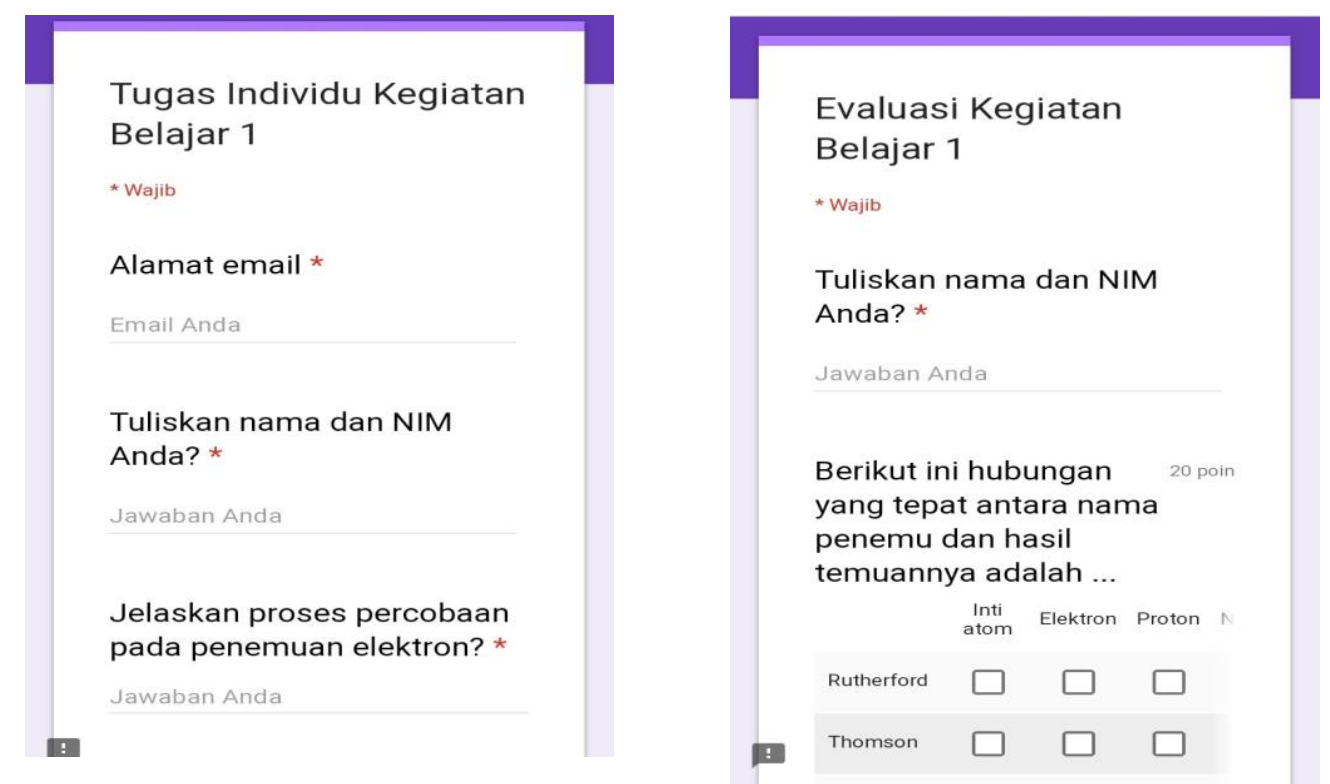

Gambar 3. Konten online pada e-modul

Hasil validasi ahli materi menunjukkan skor $93 \%$ pada aspek substansi tujuan, materi, dan evaluasi pembelajaran, $88 \%$ pada aspek akurasi materi, dan $100 \%$ pada kemutakhiran materi. Berdasarkan hal tersebut maka e-modul sangat valid dilihat dari aspek materi. Hasil validasi ahli media menunjukkan jika e-modul sangat valid. Hal ini terlihat dari skor validasi pada aspek kriteria penyajian sebesar $85 \%$ dan pada aspek kriteria kegrafikan sebesar $94 \%$. Hasil validasi ahli bahasa juga menujukkan jika e-modul sangat valid dilihat dari aspek 
komunikatifitas tujuan materi \& evaluasi sebesar $83 \%$, aspek dialok dan interaktif sebesar $75 \%$, aspek kelugasan tujuan materi \& evaluasi sebesar $100 \%$, aspek keruntutan antar topik subtopik \& paragraf sebesar $75 \%$, dan aspek penulisan istilah/simbol/lambang sebesar $100 \%$. Berdasarkan hasil validasi maka dapat dikatakan e-modul memiliki validitas sangat valid sehingga dapat digunakan tanpa revisi (Akbar, 2015). Uji coba yang dilakukan terhadap mahasiswa untuk mengetahui keterterapan emodul dilihat dari aspek isi, penyajian, bahasa, dan pendekatan blended learning menunjukkan hasil $90 \%, 82 \%, 94 \%$, dan $87 \%$. Hasil ini menunjukkan jika e-modul struktur atom direspon sangat baik oleh mahasiswa.

\section{KESIMPULAN}

Hasil penelitian menunjukkan bahwa emodul berbasis $e P U B$ pada materi struktur atom memiliki validitas sangat valid ditinjau dari ahli materi, ahli media, dan ahli bahasa. Hasil keterterapan e-modul pada aspek isi, penyajian, bahasa, dan pendekatan blended learning menunjukkan kategori sangat baik. Dengan demikian e-modul struktur atom sangat layak digunakan pada pembelajaran kimia dasar berbasis blended learning.

\section{DAFTAR RUJUKAN}

Akbar, S. (2015). Instrumen Perangkat Pembelajaran. Bandung: PT. Remaja Rosdakarya.

Chang, R. (2010). Chemistry $10^{\text {th }}$ Edition. New York: Mc Graw Hill.

Chomchid, P. (2008). Using Visuospatial Models to Enhance Teaching And Learning of Atomic Structure And The Periodic Table In High School Chemistry. Thesis tidak diterbitkan. Jerman: Kasetsart University.

Eggen, P., \& Kauchak, D. (2004). Educational Psychology: Windows on Classrooms, $6^{\text {th }}$ Edition. Upper Saddle River: Pearson Education, Inc.

Erduran, S. \& Scerri E. (2002). The Nature of Chemical Knowledge and Chemical Education. Dalam J.H.V. Driel, J.K.Gilbert, O.D. Jong, R. Justi, \& D.F. Treagust (Eds.), Chemical Education: Toward Research based Practice (hlm. 727). Netherlands: Kluwer Academic Publishers.

Falvo, D.(2008). Animations and Stimulations for Teaching and Learning Molecular
Chemistry. International Journal of Technology in Teaching and Learning, 4 (1): 68-77.

Gilbert, J.K. (2005). Visualization in Science Education. Dordrecht: Springer.Nakiboglu, $\quad$ C. 2003. Instructional Misconception of Turkish Propective Chemistry Teachers about Atomic Orbital and Hybridization. Chemistry Education: Research and Practice. 4(2): 171-188.

Kirna, I. M. (2014). Pengembangan Konten Online untuk mendukung Blended Learning pada Perkuliahan Kimia Kuantum Dasar. Cakrawala Pendidikan, XXXIII (2): 186-197.

Ozmen, H. (2004). Some Student Misconceptions in Chemistry: A Literature Review of Chemical Bonding. Journal of Science Education and Technology, 13(2): 147-159.

Passerini, K. (2007). "Performance and Behavioral Outcomes in TechnologySupported Learning: The Role of Interactive Multimedia". Journal of Educational Multimedia and Hypermedia, 16(2):183-210.

Puslitjaknov. (2008). Metode Penelitian Pengembangan. Jakarta: Depdiknas.

Sanger, M.J., Campbell, E., Felker, J., \& Spencer, C. (2007). Concept Learning versus problem Solving: Does Particle Motion Have Effect?. J.Chem. Educ, 84 (5): 875 .

Schunk, D.H., Pintrich, P.R., \& Meece, J.L. (2008). Motivation in Education: Theory, Research, and Application. Upper Saddle River: Pearson Education, Inc.

Stieff, M. (2005). Connected Chemistry: A Novel Modelling Environtment for The Chemistry Classroom, (Online), 82 (3). (http://www.JCE.DivCHED.org).

Taber, K.S. (2001). Building the Structural Concepts of Chemistry: Some Considerations from Educational Research. Chemistry Education : Research and Practice in Europe, 2 (2): 123-158.

Wardhani, N.K, Prayitno, \& Fajaroh, F. (2016). Studi Pemahaman Konsep dan Miskonsepsi Calon Guru Kimia pada Topik Struktur Atom menngunakan Instrumen Diagnostik Two Tier. Jurnal Pembelajaran Kimia, 1 (2): 38-41. 